\title{
Teacher's Readiness Level in Implementing Work from Home Policy in Indonesia
}

\author{
David Malchiel Ravanelli \\ Department of Public Administration Faculty of Administrative Science, University of Indonesia \\ (email: damalchiel16@gmail.com) \\ Riezky Purnama Ersani Putri \\ Department of Public Administration Faculty of Administrative Science, University of Indonesia \\ (email: riezkypurnama18@gmail.com) \\ Zahra Karyna Putri \\ Department of Public Administration Faculty of Administrative Science, University of Indonesia \\ (email: zahrakaryna@gmail.com) \\ Lina Miftahul Jannah \\ Department of Public Administration Faculty of Administrative Science, University of Indonesia \\ (email: miftahul@ui.ac.id)
}

\begin{abstract}
During the Covid-19 pandemic, the Indonesian Government has implemented Work from Home policy for government employees, including teachers. The duties and obligations of teachers are unique compared to other government employees who provide more administrative services. The teacher must deliver learning to students, whose ultimate goal is to measure student's abilities on the curriculum. This paper will describe the readiness of teachers in implementing the Work from Home Policy. This study uses the Readiness for Organizational Change theory with four readiness dimensions, namely appropriateness, management support, change-specific efficacy, and personal valence. This study uses quantitative approach by online survey, through accidental sampling, which is analysed with different tests, Mann-Whitney U Test and Kruskal-Wallis H Test. The results show that all dimensions of readiness are at moderate level, and there are differences in the level of teacher's readiness when compared by regional and age, and there is no difference in the level of teacher's readiness when compared by education level.
\end{abstract}

\section{Keywords:}

level of readiness; readiness; teacher; work from home

\section{Introduction}

The Covid-19 pandemic declared by the World Health Organization (WHO) as a global pandemic is one of the challenges faced by the industrial revolution 4.0 era. This pandemic was declared a non-natural national disaster. As a result of its rapid and massive 
spread, this pandemic requires the government to enact a new policy for the State Civil Apparatus, including adjusting the working system. The instruction for adjusting the working system is listed in the Circular Letter of the Minister of Administrative and Bureaucratic Reform Number 19 of 2020 on Adjustments to the Work System of the State Civil Apparatus in Efforts to Prevent the Spread of Covid-19 in Government Agencies. One form of adjustment to the work system is that the state civil apparatus can carry out official duties by working at home or working from home (WFH), but it needs to be regulated and adapted by each institution so that they can continue to pay attention and don't interfere government processes and services to the citizen. The implementation of this policy is valid until $31^{\text {st }}$ March 2020, then extended to $21^{\text {st }}$ April 2020 through Circular Letter of the Minister of Administrative and Bureaucratic Reform Number 34 of 2020. This policy is a response to the extension of the status of a certain emergency situation for the Covid-19 disease outbreak in Indonesia that has been issued by the National Disaster Management Agency (BNPT). Finally, in the Circular Letter of the Minister of Administrative and Bureaucratic Reform Number 58 of 2020 concerning the Work System for State Civil Apparatus in the New Normal Order, it is emphasized that the state civil apparatus continues to carry out its duties and functions productively. The work system in the New Normal Order for State Civil Apparatus is flexible and adjusted to the status of Large-Scale Social Restrictions in each region.

The policy made by the Ministry of Administrative and Bureaucratic Reform has also produced specific policies in each ministry. For example, teachers, most of whom have the status of Regional State Civil Apparatus, also have to make adjustments to the work system in view of the circular state of the Minister of Administrative and Bureaucratic Reform. So, the Minister of Education and Culture adapt and make efforts to prevent the spread of Covid19 in educational settings by issued a Circular Letter of the Minister of Education and Culture Number 4 of 2020 on the Implementation of Education Policies in an Emergency Period of the Spread of Covid-19 which was strengthened by the Minister of Education and Culture Circular Number 15 of 2020 on Guidelines for Organizing Learning from Home in an Emergency for the Spread of Covid-19 (Kamil, 2020; Ministry of Education and Culture Website Manager, 2020).

The methods and media for implementing Learning from Home which are carried out by Distance Learning (Pembelajaran Jarak Jauh or PJJ) are divided through two approaches, 
online with 23 pages of learning resources for students and offline through the use of learning programs through Indonesia television (TVRI), radio, printed teaching materials, self-study modules, and worksheets, and props from the surrounding environment (Ministry of Education and Culture Website Manager, 2020). Based on the Joint Decree between the four ministers, learning methods in the new normal era will be carried out according to the zone; for schools in the red, orange, and yellow zones it is recommended to continue implementing PJJ, but for schools in the green zone they can carry out face-to-face learning while still following health protocols (P3GTK, 2020).

However, the distance learning platform, online and offline, will be permanent with the aim of developing the competence of students in global competition (Ministry of Education and Culture Website Manager, 2020). The Director General of Teachers and Education Personnel of the Ministry of Education and Culture stated that the Ministry of Education and Culture encourages the use of a combination or hybrid model so it still in line with the goal of creating superior and innovative human resources to face the industrial revolution 4.0 (Ministry of Education and Culture Website Manager, 2020). Implementation of distance learning that utilizes technology-based learning methods provides various opportunities to catalyze the implementation of education 4.0 (Anas, 2020). Distance learning offers a variety of facilities and opportunities to learn independently and think critically in reaching and understanding such a wide range of knowledge (Anas, 2020). In line with the use of technology, distance learning requires education units to have the capacity and competence to utilizes technology (Ministry of Education and Culture Website Manager, 2020).

There are still some obstacles from the learning from home method that become challenges for the government. The Coordinating Minister for Human Development and Culture stated that distance learning had more disadvantages than strengths, and the supporting facilities for distance learning were not evenly distributed and adequate (CNN Indonesia, 2020). The Indonesian Child Protection Commission (KPAI) then argued that the government should map the community's constraints during distance learning first, so that the assistance provided is right on target, fair and equal (Liputan6.com, 2020). In addition, other problems exist relating to the number of teachers in Indonesia. The Ministry of Education and Culture predicts that Indonesia will experience a shortage of 1 million teachers 
each year in the period 2020-2024 (CNN Indonesia, 2020). Furthermore, the need for the number of teachers increased by $1000 \%$ during the Covid-19 pandemic, even though previously the distribution of teachers was still uneven (Sulaiman, 2020). Other obstacles noted by the Indonesian Ombudsman based on public complaints about the implementation of distance learning, include the duration between subjects that are too congested, the internet network, inadequate technical support facilities, and the availability of mentoring time by parents of students (JPNN.com, 2020).

Based on a survey conducted by the Ministry of Education and Culture in April 2020, $86.6 \%$ of teacher activities were only giving questions, while online interactive learning is less than $40 \%$ (Muhammad, 2020). It caused several problems, such as: First, there are many complaints from students regarding the workload that they feel are increasing (Alam, 2020); Second, $67.11 \%$ of respondents stated that the lack of teacher's ability to operate digital devices was a major obstacle during distance learning; Third, things are related to supporting facilities (internet devices and networks), internal support and student environment, teacher support, and the inability to effectively monitor student development (Muhammad, 2020).

Based on Ashal (2020), the implementation of WFH increases the productivity of the State Civil Apparatus, because the working atmosphere at home is more pleasant, but is constrained by the limitations of technological devices. Setyawan and Lestari (2020) stated the obstacles related to the implementation of WFH, including the presence of employees who are not capable of the use of technology and cannot differentiate between work-life and homelife. Rereferring to the level of productivity in implementing WFH, Wahyu and Sa'id (2020) showed in psychological perspective, WFH can increase productivity due to the influence of social facilitation, and vice versa can reduce productivity due to social loafing conditions. Mustajab, et al. (2020) concluded that organizations that provide work facilities have the potential to implement WFH effectively, but there are areas of work that cannot be implemented effectively through WFH, such as direct services, as well as the impact of implementing WFH based on a gender perspective, namely giving disadvantages to married women due to multitasking between office and home work. In line with the field of work in WFH, Tuti (2020) also showed that the WFH policy has a negative impact on online transportation services, which results in a decrease in the level of employee welfare in that sector. 
Regarding the implementation of WFH on teachers, many studies have been conducted. As a matter of fact, the implementation of WFH on teachers has positive and negative impacts. Flexibility in working time, saving transportation costs, and minimizing stress levels due to traffic jam are the positive impacts, on the other hand, saturation of the work atmosphere, disruption of work focus, data security problems, and decreased quality of learning are the negative impacts (Purwanto, 2020; Rokhani, 2020). Related to the quality of distance learning, the WFH policy has reduced the quality of learning and teaching process due to the lack of teacher's ability to operate learning applications and limited interaction with students. In addition, there are obstacles in the implementation of WFH due to the low digital competence of teachers, instability of the internet network, and difficulties in managing learning, assessment and supervision (Busyra and Sani, 2020; Rigianti, 2020; Alfiah, et al., 2020; Mastura and Santaria, 2020).

The explanations above describe that the readiness of teachers as a civil apparatus in implementing distance learning in the framework of WFH policies is not optimal, both in terms of technology use and innovation in providing learning. In fact, the readiness of teachers in implementing WFH is a key strategy that determines the implementation of WFH policies to continue in the productivity corridor. WFH as a work system with the use of technology will be closely related with the readiness of a large number of teachers and will have a strong influence on the performance of state civil apparatus teachers in the new work system. Therefore, the subject matter discussed is, "How is the Readiness of Teachers in Implementing the Work From Home Policy".

\section{Methods}

This study uses a quantitative approach to measure the level of teacher's readiness in implementing WFH policies, based on the theory of Readiness for Organizational Change by Holt, Armenakis, Feild and Harris (2007) through four readiness dimensions, namely Appropriateness, Management Support, Change-Specific Efficacy, and Personal Valence. Appropriateness is defined as the belief that certain changes are appropriate to address the situation in the organization that is being handled. There are two components in Appropriateness, namely Discrepancy, which refers to the level of individual belief that change initiatives are needed because it is a necessity and there are legitimate reasons for 
initiating change and Organizational Valence which refers to the level of individual belief that change will benefit the organization. Management Support or can be referred as Senior Leader Support refers to the level of individual belief that the leader in the organization is committed to and supports the implementation of change. Change requires commitment to implementing institutionalization, because if there is no clear support from the leader, then individuals in the organization tend to be skeptical and inactive to support the implementation of change. Management Support represents the Change Process perspective in an individual readiness model, so that the role of the leader is closely related to the steps taken during the change in implementation. Change-Specific Efficacy or can be referred as Self-Efficacy refers to the level of individual belief that his or her has the abilities and skills to carry out tasks and activities when these changes are carried out, the extent to which the individual feels sure he will perform well and do his job successfully. Finally, Personal Valence or can be referred as Personally Beneficial refers to the level of individual belief that the proposed changes are personally beneficial to individuals. Individuals will assess the positive and negative outcomes of change for themselves, the fairness of change initiatives, and how individuals are treated during the change process is implemented. Individual resistance to organizational change will arise when individual personal interests are threatened.

Descriptive research is used with a purpose to describe and analyse a social phenomenon, that is regarding the readiness of teachers in implementing WFH policies. In collecting primary research data, quantitative method techniques were used through online surveys and literature reviews. This study used an online survey technique that was distributed from 6 to 10 August 2020, consisting of 25 closed questions and 5 semi-open questions. The formulation of closed questions using a Likert scale with four categories (Strongly Agree, Agree, Disagree and Strongly Disagree), its intended to measure the level of respondent agreement on a statement based on indicators of the theory of Holt, Armenakis, Feild, and Harris (2007).

The population were state civil apparatus teachers divided by city or regency domicile, age, and education level. This study used a non-probability technique, quota sampling, with 82 respondents. A literature review was carried out in 5 journals regarding WFH policies, as 
well as 6 journals regarding the implementation of WFH for teachers. The data that was collected was then processed using quantitative data analysis techniques.

The hypothesis that is built is:

1. Ho1: There is no significant difference between the Readiness of Teachers to implement the WFH Policy between those living in the City and the District Ha1: There is a significant difference between the Readiness of Teachers to implement the WFH Policy between those living in the City and the District

2. Ho2: There is no significant difference between Teachers' Readiness to implement the WFH Policy between those categorized as millennial ages and non-millennial ages Ha2: There is a significant difference between the Readiness of Teachers to implement the WFH Policy between those categorized as millennial and non-millennial ages

3. Ho2: There is no significant difference between the Readiness of Teachers to implement the WFH Policy when viewed from their education (Undergraduate, Postgraduate, and Vocational)

Ha2: There is a significant difference between the Readiness of Teachers to implement the WFH Policy when viewed from their education (Undergraduate, Postgraduate, and Vocational)

Quantitative data analysis processed through SPSS (Statistical Product and Service Solution) software using the Mann Whitney U Test to measure differences in the readiness of teacher groups based on domicile and age, and the Kruskal Wallis $\mathrm{H}$ Test to measure differences in the readiness of teacher groups based on education level.

\section{Results and Discussion}

\section{a. Teleworking}

The challenge faced by public organizations is adapting to social, administrative, and technological changes. One of the organizational innovations that are increasingly being adopted in public organizations is teleworking which is expected to improve the working conditions of state civil apparatus (De Vries, Tummers, \& Bekkers, 2019). The implementation of teleworking is expected to support employees in balancing work and personal life and improve organizational performance (Groen, Triest, Coers, \& Wtenweerde, 2018). Therefore, employees have been given the opportunity to carry out some or all their duties at home or in alternative locations (Caillier, 2012). 
Telework or telecommuting, is a flexible working arrangement, where employees carry out all or most of their work physically separated from the employer's location using the assistance of information and communication technology or ICT (Baruch, 2001; De Vries, Tummers, \& Bekkers, 2019). There are three types of teleworking: 1) home-based telework, when employees carry out work at home; 2) teleworking from remote offices, when employees carry out work in offices that are far from the head office; 3) mobile telework, when employees carry out work that involves traveling and/or spending time at the customer's place (Daniels, Lamond, \& Standen, 2001). In this study, teleworking is referred as work from home, as it is used throughout the world, especially in the presence of the Covid-19 pandemic which has increased the number of employees working from home (Baert, Lippens, Eline, Sterkens, \& Weytjens, 2020). The term work from home is also in line with one of the types of teleworking proposed by Daniels, Lamond, and Standen (2001), namely home-based telework.

\section{b. Teacher's Competence}

Various studies in the field of pedagogy have found various perspectives that are closely related to three important factors of education, namely educational attainment (success), professional development, and social change (Suciu \& Mâţă, 2011). Pedagogic competence is the ability of individuals to coordinate and synergize the combination of tangible resources (such as teaching materials, books, articles, technology, hardware, and software) and intangible resources (such as knowledge, skills, and experiences) to achieve efficiency and/or effectiveness pedagogy (Madhavaram \& Laverie, 2010). Gliga in Suciu and Mâță (2011) defines pedagogic competence as a professional minimum standard determined by laws and regulations that require teachers to fulfil their roles. The standard of teacher professionalism is related to teacher skills that are adjusted to the context of external pressure reactions, public discourse, and scientific developments (Demirkasimoglu, 2010).

In a more specific context, pedagogical competence reflects teacher competence in relation to collaboration, comprehensive views, and contributions to pedagogical development for education (Ryegård, Apelgren, \& Olsson, 2010). Teacher's pedagogical competence in empowering students to face the challenges of the $21^{\text {st }}$ century must be renewed and developed, because the digital revolution that is happening today needs to be balanced with the transformation of the education, teaching and learning system in schools. 
Therefore, it is necessary to develop pedagogical competencies by integrating knowledge, pedagogy, and technology (Caena \& Redecker, 2019; Fullan \& Langworthy, 2014). This pedagogic competence supports the role of teachers in creating environments and opportunities through learning experiences for students to find and improve their capacities (Caena, 2017)

In relation to the implementation of $\mathrm{WFH}$, pedagogical competence is important. As stated in Government Regulation Number 74 of 2008 on Teacher Article 3 paragraph (4), the

pedagogical competence includes at least: a) understanding of educational insight or foundation; b) understanding of students; c) curriculum or syllabus development; d) learning design; e) the implementation of educational and dialogical learning; f) utilization of learning technology; g) evaluation of learning outcomes; and h) development of students to actualize the various potentials it has.

\section{c. Facts about Education in Indonesia}

Based on data on July 2020, the number of teachers throughout Indonesia reached 2,920,672 people. The highest number of teachers is teaching at the Elementary School level (SD) as many as 1,580,207 people. There are currently 675,733 teachers working at the junior high school level, 321,914 at the high school level, 315,553 people teach at the vocational school level, and the rest teach at special schools. The total number of students was $45,684,771$ children, and around $76.62 \%$ attended state schools or government-owned educational units (PDSPK). When compared to the number of teachers and students, the ratio is 1:16. According to the Regulation of the Minister of Education and Culture Number 23 of 2013, the number of students in each study group for elementary school is not more than 32 students, and for junior high school is not more than 36 students, which means, the ratio that Indonesia has is more than ideal. However, in fact, the distribution is uneven. More than 647 thousand teachers are on the island of Java, with the highest number in East Java as many as 190.8 thousand people, while the smallest number of teachers is in North Kalimantan at 5.8 thousand.

At the beginning of the leadership of the Minister of Education and Culture, Nadiem Makarim, once alluded to the discourse of national teacher rotation. This is to ensure maximum education distribution in each region. However, until now, this plan has not been implemented. During the previous ministerial period (2018) a zoning policy had also been introduced so that teacher distribution could be carried out. The education zoning system is 
a long-term strategic policy to accelerate the distribution of education quality throughout Indonesia. The impact of this zoning system does not only regulate the priority of students in choosing schools based on distance, but also the issue of teacher's equity. So far, many regions have complained about a shortage of teachers with the status of state civil apparatus, this thing has apparently disturbed the system and learning process in the classroom. In big cities, the number of teachers with the status of state civil apparatus exceeds the quota, while in other regions, there is not even a single state civil apparatus teacher. Through the education zoning system, teachers can be mapped and distributed based on their status, so that there is no surplus of teachers in one school.

The Ministry of Education and Culture also noted that the number of certified teachers in Indonesia has not reached $50 \%$, even though certification is a measure in determining professional eligibility. The highest percentage of certified teachers is at the junior high school of $48.44 \%$, and the smallest percentage is at vocational school which is only $28.49 \%$ (Jayani, 2019). Teacher certification is the mandate of Law Number 14 of 2005 on Teachers and Lecturers. Teacher certification purposes to determine the eligibility of teachers in carrying out their duties as learning agents. In addition, it purposes to improve the process and quality of educational outcomes. To increase the capacity and ability of teachers, the government provides teacher competency training to have dual expertise. Until 2019, there were 6,077 teachers who had dual expertise and 1.66 million teachers who had attended the training. In the framework of this industrial revolution 4.0, teacher competence is very important. Based on the Ministry of Education and Culture's data, during the Covid-19 pandemic there were $96.6 \%$ of students studying from home. As many as $86.6 \%$ of Indonesian students studied at home by doing assignments from the teacher, and interactive learning was only successfully carried out by $38.8 \%$.

The implementation of the WFH policy has affected the readiness of teachers in the process of teaching and learning activities in Indonesia during the Covid-19 pandemic emergency period. The number of teachers currently available is apparently not comparable to the number of teachers who are able to utilize technology tools and learning platforms, only $40 \%$ of the total teachers are technology literate (Febryan \& Rizkyan Adiyudha, 2020). In fact, the ability of teachers to utilize technology is one of the determining factors for the readiness of implementing WFH policies to comply with productivity standards. The results of the 
evaluation of the Ministry of Education and Culture, learning from home experienced obstacles, namely as many as $53.55 \%$ of teachers had difficulty managing the class during PJJ, and $49.24 \%$ of teachers were hampered from carrying out PJJ assessments. Teachers also find it difficult to use technology during PJJ, with a total of $48.45 \%$.

In addition to simplifying basic competencies, the Emergency Curriculum established during the Covid-19 pandemic is a simplification of basic competencies that refers to the 2013 curriculum, which focuses on essential competencies and prerequisite competencies for continuing learning at the next level. One of the most important points in the emergency curriculum is that the teacher does not need to force the completeness of the curriculum, but only chooses essential learning. For example, if the teacher feels overloaded with the existing curriculum, then they can use a simple curriculum, or a curriculum mapped by schools themselves.

\section{d. Respondent Characteristics}

The questionnaire sent through the online survey received responses from 82 teachers whose characteristics are illustrated in the following chart.

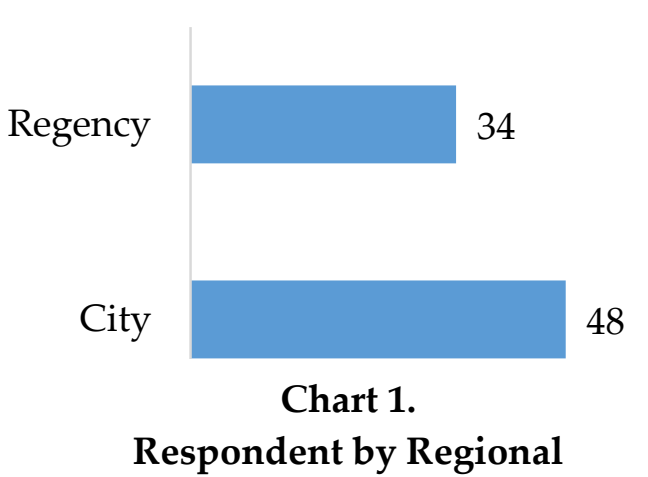

Source: Obtained from Primary Data, 2020
Although respondents spread throughout Indonesia, most of the respondents $(76.83 \%)$ resided in Java Island. Chart 1. illustrates that most of the respondents work in the City area. Many people have the view that the City area is always more advanced or modern than the Regency area, and people admit to being embarrassed when they mention they come from the Regency. In fact, based on existing regulations in Indonesia, there is no specific distinction between cities and districts. Article 2 of Law Number 23 of 2014 concerning Regional Government only states that "the Unitary State of the Republic of Indonesia is divided into provincial regions and provincial areas are divided into regencies and cities; Regency/city areas are divided into Districts and Districts divided into sub-districts and/or villages." This law also does not stipulate specific matters regarding the differentiation between the division of authority between regencies/cities, because it is always written with a slash symbol. The only clear difference is in the name of the officer who heads, the Regency 
is led by the Regent, while the City is led by the Mayor. Another difference as stated in Article 8 of Government Regulation Number 78 of 2007 on Procedures for Establishing, Eliminating, and Merging the Regions is that the formation of Regency is at least five sub-districts; and the formation of the city is at least four districts. Apart from that, there is also no mention of a capital in a city (Article 12). In its implementation, the smallest government at the cities are the sub districts, while at the regencies are the sub-districts and villages.

If we described further, the differences can be mapped into five aspects:

a. In terms of area, the regency's government area is relatively wider than the city's area. Therefore, in the district area there are many underdeveloped villages, meanwhile, to reach equitable development throughout the region, a larger budget is required.

b. The demographic aspect, the population density in regencies is lower than in cities. Population density is a problem for local governments in terms of providing employment, education, health, and overcoming social problems.

c. the aspect of people's livelihoods, the regency population is generally engaged in agriculture or is agricultural in nature, while urban residents are engaged in trade and services. In the making of regional development policies, the priorities in regency's governments will differ from those in cities governments, especially in terms of implementing optional functions in the regions.

d. the socio-cultural aspect, cities residents have better levels of education and health than regencies. Public service facilities are also better in cities than in regencies.

e. the economic aspects, the average Gross Regional Domestic Product (GRDP) in districts is lower than that of cities.

Chart 2. below illustrated that there is only one respondent who has a vocational education, while the other respondents are in accordance with the legislation. In Indonesia, teacher management is regulated in Law Number 14 of 2005 on Teachers and Lecturers. It is stated in this law that teachers are professional educators with the main task of educating, teaching, guiding, directing, training, assessing, and evaluating students in early childhood education through formal education, basic education, and secondary education. 


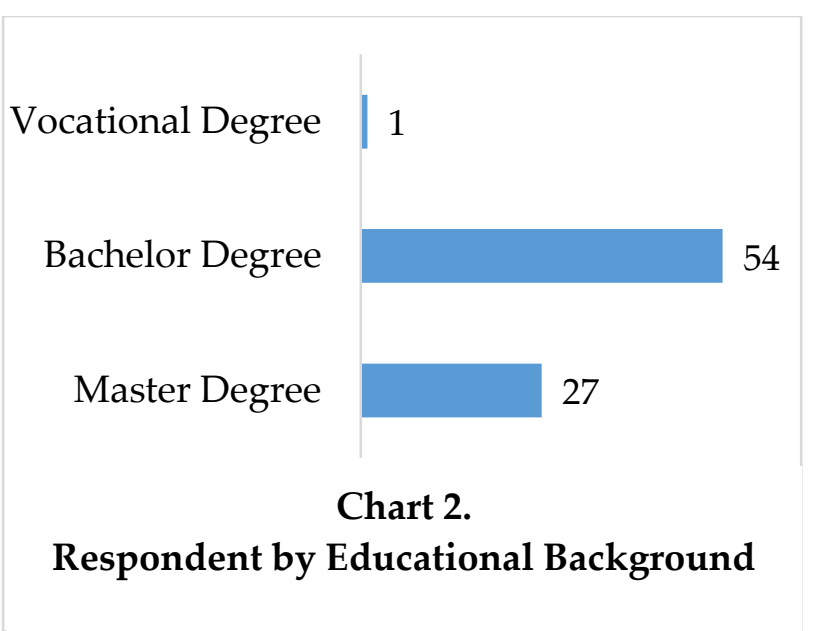

Source: Obtained from Primary Data, 2020

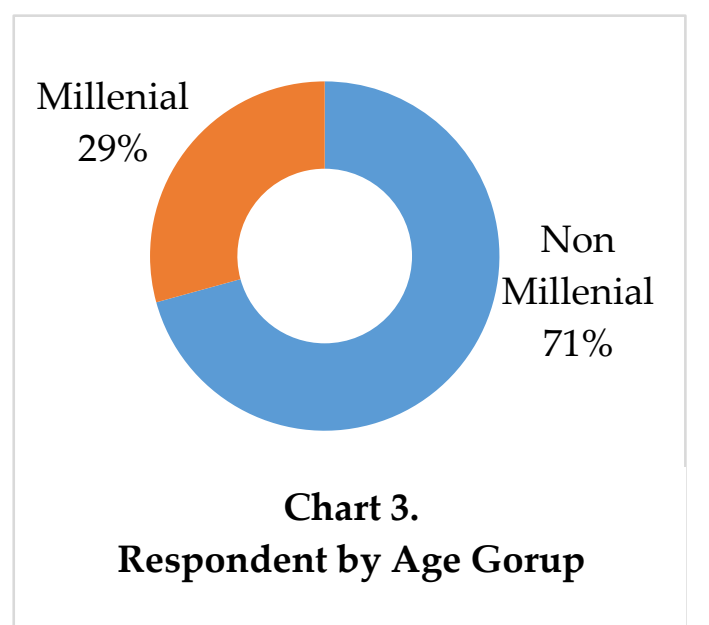

Source: Obtained from Primary Data, 2020

In accordance with Law on Teachers and Lecturers Chapter IV article 8, there are five requirements for a teacher: 1) has academic qualifications, which is to have a bachelor's degree and/or a relevant skill certificate accordingly. prevailing statutory provisions; 2) has competencies which include personal, pedagogic, professional, and social competences; 3) has educator certificate as formal evidence of teacher recognition as professional staff; 4) has a healthy body, and 5) has the ability to achieve the goals of national education, namely to develop the potential of students to become human beings who believe and have devotion to God Almighty, have noble character, are healthy, knowledgeable, capable, creative, independent and become a democratic and responsible citizen. Until now, there are still 249,827 teachers $(16.66 \%)$ who do not have a bachelor's degree certificate.

Chart 3. illustrated understanding of Information Technology as a prerequisite for implementing WFH policies in education is needed. Millennial generation refers to individuals under 40 years of age, while non-millennial ages are 40 years and over. Previous studies have shown that many of the characteristics inherent in millennial employees are not owned by previous generations and are closely related to innovation behavior. The results of Cogin (2012) study concluded that millennials are always interested in new challenges in their workplace, whereas, Ng \& Gossett (2013) states that millennial generations tend to be more confident, ambitious, have strong social sensitivity, value diversity, and want to contribute to their organization. Nowadays, there is an increase in the number of millennial employees in the public sector. In 2019 , there were approximately $1,419,691$ or $33.89 \%$ of the total number of employees. This number increased compared to 2018 which was 1,363,472 or $32.63 \%$ of the total employees (Central Statistics Agency, 2020). Although currently the number of 
millennial employees is still smaller than Generation X employees, the number is expected to increase along with the peak of Indonesia's demographic bonus in 2030.

\section{e. Teacher's Readiness Level in Implementation of WFH Policy}

This section discusses the results of research related to teacher's readiness as illustrated in the chart below.

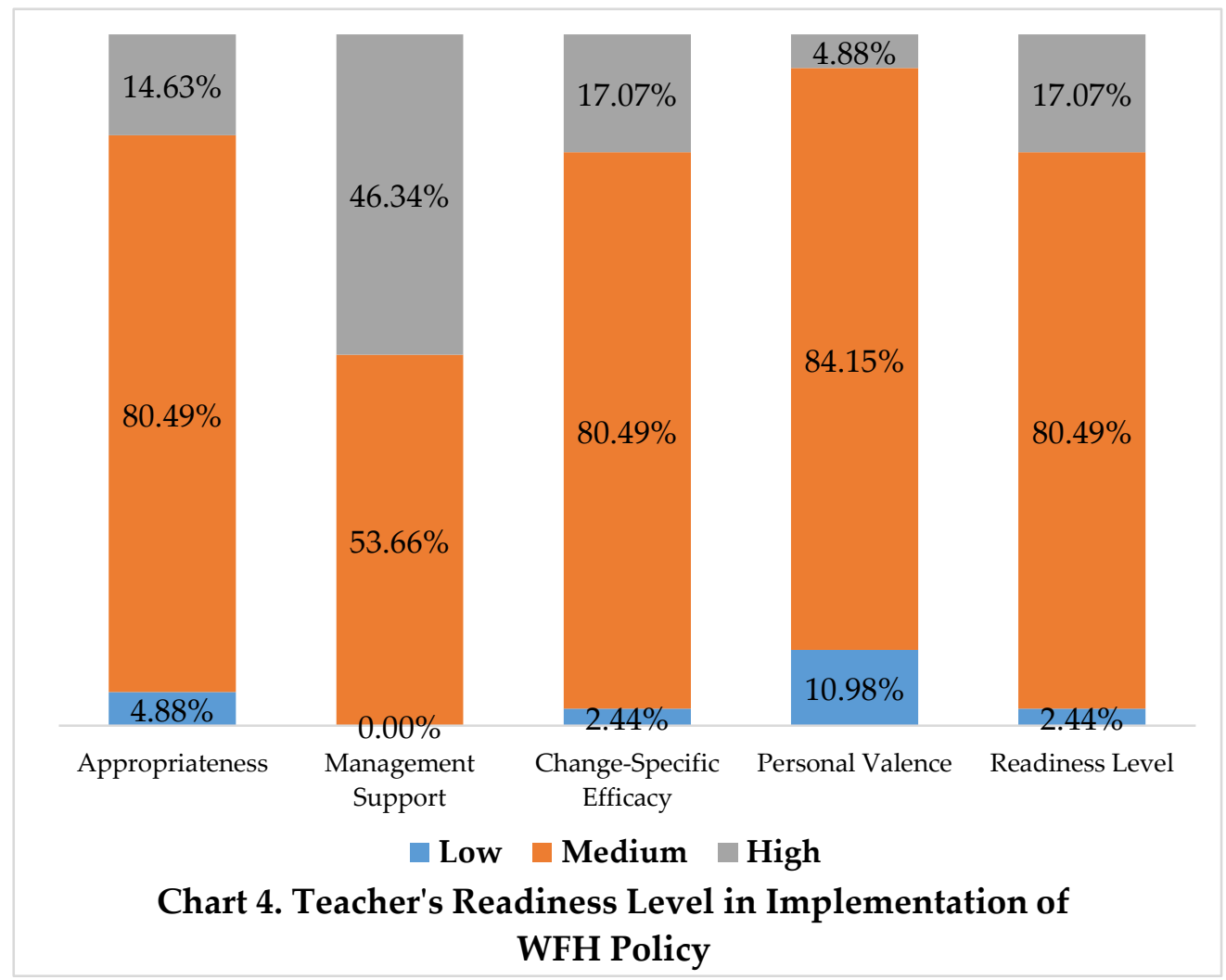

Source: Obtained from Primary Data, 2020

In all dimensions, the readiness was mostly in the medium category. The management support dimension shows the highest percentage of high readiness $(46.34 \%)$, while the personal valence dimension has the smallest percentage (4.88\%). Overall, the level of teacher readiness to implement WFH was mostly in the medium category $(80.49 \%)$. The four dimensions that exist are the manifestation of the level of teacher's belief cognitively and emotionally which can shape individual teacher readiness in facing WFH.

In the appropriateness dimension, related to the level of teacher's belief that WFH is needed by the organization, in accordance with the situation, and beneficial for the organization in the long term, as many as $80.49 \%$ (66 respondents) had a moderate level of belief. This is actually also supported by the Minister of Education and Culture, who stated 
that teaching and learning activities should be carried out at home using the use of technology, especially in areas that are still not safe from the threat of Covid-19 (Harususilo, 2020). The appeal is also related to adjusting the state civil apparatus work system in effort to prevent the spread of Covid-19 within government agencies. The number of schools implementing PJJ has also increased along with the growth of Covid-19 cases in Indonesia, as of the end of March 2020, only 54\% of schools were implementing PJJ (Ramadhan, 2020). That number increased in May 2020 to $97.6 \%$ of schools, as stated by the Minister of Education and Culture (Shofa, 2020).

In the management support dimension, related to the level of teacher's belief in agency leaders in terms of commitment, communication and support to individuals during the implementation of WFH, as many as $53.66 \%$ (44 respondents) had a moderate level of belief. Support from the leaders can be seen through various policies issued by the Minister of Education and Culture. As long as the teacher implements WFH or distance learning, such as relaxing the use of School Operational Assistance (BOS) funds which can be used to finance school needs, issuing an emergency curriculum that can be tailored to the learning needs of students, as well as learning modules to make it easier for teachers to teach (Ihsan, 2020 ; Ministry of Education and Culture Website Manager, 2020). Currently, the government has also provided supporting facilities for the implementation of $\mathrm{WFH}$, in the form of providing learning quotas, as well as other supporting infrastructure. The Minister of Education and Culture also actively communicated with teachers and schools during the Covid-19 pandemic, either by visiting in person or virtually by providing advice and motivation (Ashar, 2020; Shofa, 2020).

In the dimension of change-specific efficacy, related to the level of teacher's belief in his or her skill and ability, as many as $80.49 \%$ (66 respondents) fall into the medium category. The change-specific efficacy dimension is also related to one of the supporting factors of WFH, namely knowledge intensity, which is the level of knowledge to complete work, and is also related to teacher pedagogical competence specifically in the use of learning technology as stated in Article 3 paragraph (4) letter f PP about Teacher. Training and development for teachers to be adaptive and innovative in facing change have also been held, according to the Secretary General of the Ministry of Education and Culture, Education and Culture Ministry 
has held various series of webinars that have been attended by 150.000 teachers (Zubaidah, 2020).

In the personal valence dimension, related to the level of teacher's belief that WFH is beneficial for him or herself, as many as $84.15 \%$ (69 respondents) categorized into the medium category. This is also supported by one of the supporting factors for WFH, namely intraorganizational contact. If explored, as many as $69.51 \%$ (57 respondents) answered that they did not have trouble communicating with internal parties, the remaining $30.49 \%$ (25 respondents) experienced difficulties. Based on research conducted by Purwanto (2020), there are several advantages for teachers from implementing WFH such as being more flexible in completing work, not following office hours, not having to spend transportation costs, minimizing stress due to traffic jam, and having more time spare (Purwanto, 2020).

\section{e. Difference test analysis}

As has been described in the research method, there are several difference tests analyses conducted.

1) Readiness of Teachers to implement the WFH Policy based on Region

From the results of the study using the Mann-Whitney $U$ test, the following results were obtained.

Test Statistics ${ }^{a}$

\begin{tabular}{|c|c|}
\hline \multicolumn{2}{|c|}{ Teacher Readiness by Region } \\
\hline Mann-Whitney U Test & 517.000 \\
\hline Z & -2.820 \\
\hline Asymp. Sig. (2-tailed) & .005 \\
\hline
\end{tabular}

Grouping Variable: Region based on Regency and City

The data in the test statistics above showed that the significance value or $\mathrm{P}$ value is 0.005. This figure is less than the critical limit or value of 0.05 , so it can be concluded that Ho1 is rejected, there are differences in readiness in implementing WFH policies between teachers who live in regencies and cities. As mentioned above, regencies and cities have different characteristics, including learning facilities. Although there are national policies, for example the curriculum, with regional autonomy, the policies of each region will be different from one 
another. One of the differences, for example, is in terms of allowances and facilities provided to teachers.

This condition was admitted by members of Commission X DPR, that there were still several obstacles that occurred during Distance Learning (PJJ), especially in rural areas (Media Indonesia, 2020). These constraints include the operation of Information and Communication Technology (ICT), the availability of infrastructure such as internet access, internal support from students, external support from the student environment, external support from the teacher environment, and so on (Muhammad, 2020). In addition, there are still 2.4\% of schools that do not implement Learning From Home (BDR) on the grounds that there is no internet network, the location of the school is in the interior, the area is not infected by Covid-19, there is no policy from the local government, and others (Muhammad, 2020).

2) Readiness of Teachers to implement the WFH Policy based on Age Categorized

The results of the Mann-Whitney $U$ Test on teacher readiness and age variables are presented in the table below

Test Statistics ${ }^{a}$

Teacher Readiness by Age

Mann-Whitney U $\quad 558.000$

Z -2.044

Asymp. Sig. (2-tailed) $\quad .041$

Grouping Variable: Age (Millennial and Non-Millennial)

Based on The Mann-Whitney U Test statistical test above showed a significance value or P Value is 0.041 which is less than the critical limit or significance value of 0.05 , so it can be concluded that $\mathrm{Ho}_{2}$ is rejected, there are differences in readiness in implementing WFH policies between teachers who grouped the millennial and non-millennial age. In line with differences on millennial and non-millennial age, the results of Wardinur and Mutuwally (2019) study showed that age is a factor that affects the ability of teachers to use educational platforms as learning media (Wardinur \& Mutawally, 2019). Refers to 58 respondents in the non-millennial age group, 55 respondents have worked experience for more than 10 years, so that the opportunity to get digital-based education and training provided by the government (Pustekkom, Balitbang, LPMP and P4TK) is much more than teachers at the millennial age. 
Regarding to pedagogical competence especially ability to utilize technology, this is more influenced by the teaching experience compared to age, so that teachers who are nonmillennial age and have worked for more than 10 years are more effective in providing learning, and encourage a higher level of readiness in implementing WFH policies (Pratiwi, 2016)

3). Readiness of Teachers to implement the WFH Policy based on educational background

The results of the Kruskal-Wallis test regarding the readiness of teachers to implement WFH policies based on their educational background can be seen in the following SPSS output.

Test Statistics

\begin{tabular}{|c|c|}
\hline \multicolumn{2}{|c|}{ Teacher Readiness by Educational Background } \\
\hline Chi-Square & 5.168 \\
\hline Df & 2 \\
\hline Asymp. Sig. & .075 \\
\hline
\end{tabular}

Grouping Variable: Educational Background

The significance value or $\mathrm{P}$ value in the research results above is 0.075 . This figure is greater than the critical limit or the significance value of 0.05 , so it can be concluded that $\mathrm{Ho}_{3}$ is not rejected. It means that there is no significant difference from the readiness of teachers in implementing WFH policies when viewed from their educational background. As stated above, the prerequisite for being a teacher is to have education at the bachelor's level. The skill factor of utilizing digital devices and supporting infrastructure is the main aspect that affects the level of readiness of teachers in implementing WFH. This is supported by Indra Charismiadji's statement as Director of CERDAS, that teachers need to be given training that involves experts, national and international education figures, so that PJJ in the coming academic year will be more prepared and run efficiently and effectively (Widyanuratikah, 2020). Even if there is one person who has a vocational education background, it is necessary to increase it with the obligation to continue to a higher level.

\section{Conclusion}

The readiness of employees to adapt to various changes is an important note for an organization. This includes how to make teachers always ready for various changes and 
developments in the Industrial Revolution 4.0. It is necessary to carry out various participatory policy innovations to realize the goals of national education. On the other hand, the government must also make breakthroughs in terms of coaching teachers, which also involves a comprehensive range of stakeholders from all parties is very necessary to make learning successful not only during the Covid-19 pandemic.

Engagement of stakeholders is needed holistically. The government (both central and local) prepares various educational facilities, including a good curriculum, standardized infrastructure, and competent teachers; Parents are expected to actively participate in teaching and learning activities at home and not relinquish responsibility for education only to schools; teachers can continue to increase their capacity to carry out interactive learning; and schools can facilitate teaching and learning activities with the most appropriate methods; teachers also have to change traditional ways of thinking and teaching methods while still paying attention to the readiness of students and existing local wisdom; and the private sector can also provide a variety of reinforcement for teachers including training and development.

\section{Acknowledgement}

This research is part of a research conducted by a group of students from the Public Administration Study Program at the Faculty of Administrative Sciences, Universitas Indonesia, with the title State Civil Apparatus Readiness in implementing The Work From Home Policy. Thank you to the other lecturers (Reza Fathurrahman, Fitria Ariyanti, and Dyah Ayu Febriani) and friends who are members of the Public Administration Research Methods Group 1.

\section{References}

\section{Books}

Fullan, M., \& Langworthy, M. (2014). A Rich Seam How pedagogies find deep learning. London: Pearson.

Ryegård, Å., Apelgren, K., \& Olsson, T. (2010). A Swedish perspective on PEDAGOGICAL COMPETENCE. Uppsala: Uppsala University. 


\section{Book chapter}

Caena, F. (2017). Weaving the fabric: Teaching and teacher education ecosystems. In B. Hudson, Overcoming fragmentation in teacher education policy and practice. Cambridge: Cambridge University Press.

\section{Journal article}

Alfiah, L. N., Rokhim, D. A., \& W, I. A. (2020). ANALISIS DAMPAK ANJURAN PEMERINTAH TERHADAP BELAJAR DI RUMAH BAGI PELAKU PENDIDIKAN. Jurnal Administrasi dan Manajemen Pendidikan, 216-223.

Ashal, R. A. (2020). PENGARUH WORK FROM HOME TERHADAP KINERJA APARATUR SIPIL NEGARA DI KANTOR IMIGRASI KELAS I KHUSUS TPI MEDAN. Jurnal Ilmiah Kebijakan Hukum, 223-242.

Baruch, Y. (2001). The status of research on teleworking and agenda for future research. International Journal of Management Reviews (IJMR) Vol. 3(2), 113-129.

Busyra, S., \& Sani, L. (2020). Kinerja Mengajar dengan Sistem Work From Home (WFH) pada Guru di SMK Purnawarman Purwakarta. Jurnal Pendidikan Islam, 1-18.

Caena, F., \& Redecker, C. (2019). Aligning teacher competence frameworks to 21st century challenges: The case for the European Digital Competence Framework for Educators (Digcompedu) . European Journal of Education Vol. 54(3), 1-14.

Caillier, J. G. (2012). The impact of teleworking on work motivation in a US federal government agency. The American Review of Public Administration, 42(4), 461-480.

Cogin, J. (2012). Are generational differences in work values fact or fiction? Multi-country evidence and implications." . The International Journal of Human Resource Management Vol. 23 (11), 2268-2294.

Daniels, K., Lamond, D., \& Standen, P. (2001). Teleworking: Frameworks for Organizational Research. Journal of Management Studies Vol. 38 No. 8, 46-59.

De Vries, H., Tummers, L., \& Bekkers, V. (2019). The Benefits of Teleworking in the Public Sector: Reality or Rhetoric? Review of Public Personnel Administration Vol. 39 No. 4, 570593.

Demirkasimoglu, N. (2010). Defining “Teacher Professionalism” from different perspectives. Procedia Social and Behavioral Sciences 9, 2047-2051. 
Groen, B. A., Triest, S. P., Coers, M., \& Wtenweerde, N. (2018). Managing flexible work arrangements: Teleworking and output controls. European Management Journal Vol 36(6), 727-735.

Holt, D. T., Armenakis, A. A., Feild, H. S., \& Harris, S. G. (2007). Readiness for Organizational Change: The Systematic Development of a Scale. The Journal of Applied Behavioral Science Vol. 43 No. 2, 232-255.

Madhavaram, S., \& Laverie, D. A. (2010). Developing Pedagogical Competence: Issues and Implications for Marketing Education. Journal of Marketing Education Vol. XX(X), 1-17.

Mastura, \& Santaria, R. (2020). Dampak Pandemi Covid-19 terhadap Proses Pengajaran bagi Guru dan Siswa. Jurnal Studi Guru dan Pembelajaran, 289-295.

Mustajab, D., Bauw, A., Rasyid, A., Irawan, A., Akbar, M. A., \& Hamid, M. A. (2020). Working from Home Phenomenon as an Effort to Prevent COVID-19 Attacks and Its Impacts on Work Productivity. The International Journal of Applied Business Tijab, 13-21.

Ng, E. S., \& Gossett, C. W. (2013). Career choice in Canadian public service: An exploration of fit with the millennial generation. Public Personnel Management Vol. 42 (3), 337-358.

Purwanto, A. (2020). Studi Eksplorasi Dampak Work From Home (WFH) Terhadap Kinerja Guru Selama Pandemi Covid-19. Journal of Education, Psycchology and Counseling Vol. 2 (1), 92-100.

Rigianti, H. A. (2020). KENDALA PEMBELAJARAN DARING GURU SEKOLAH DASAR DI KABUPATEN BANJARNEGARA. Journal Elementary School 7, 297-302.

Rokhani, C. T. (2020). Pengaruh Work From Home (WFH) Terhadap Kinerja Guru SD Negeri Dengkek 01 Pati Selama Masa Pandemi Covid-19. Journal of Education, Psychology and Counseling, 424-437.

Setyawan, F. E., \& Lestari, R. (2020). CHALLENGES OF STAY-AT-HOME POLICY IMPLEMENTATION DURING THE CORONAVIRUS (COVID-19) PANDEMIC IN INDONESIA. Jurnal Administrasi Kesehatan Indonesia, 15-20.

Suciu, A. I., \& Mâță, L. (2011). Pedagogical Competences - The Key to Efficient Education. International Online Journal of Educational Sciences Vol. 3(2) , 411-423.

Tuti, R. W. (2020). Analisis Implementasi Kebijakan Work From Home pada Kesejahteraan Pengemudi Transportasi Online di Indonesia. Jurnal Ilmiah Ilmu Administrasi, 73-85. 
Wahyu, A. M., \& Sa'id, M. (2020). PRODUKTIVITAS SELAMA WORK FROM HOME: SEBUAH ANALISIS PSIKOLOGI SOSIAL. Jurnal Kependudukan Indonesia, 53-60.

Wardinur, \& Mutawally, F. (2019). Peningkatan Kompetensi Guru Melalui Pelatihan Pemanfaatan Teknologi sebagai Media Pendukung Pembelajaran di MAN 1 Pidie. Jurnal Sosiologi USK, 167-182.

\section{Newspaper article on website}

Alam, S. (2020, Maret 23). Belajar di Masa Pandemi. Retrieved from Media Indonesia: https://mediaindonesia.com/read/detail/298260-belajar-di-masa-pandemi

Anas, A. (2020, September 7). Tantangan dan Peluang PJJ di Era New Normal. Retrieved from Media Indonesia: https://mediaindonesia.com/read/detail/342732-tantangan-danpeluang-pjj-di-era-new-normal

Ashar, S. (2020, Agustus 7). Nadiem Makarim: Kami ingin cepat dan seaman mungkin mengembalikan belajar di sekolah. Retrieved from KONTAN: https://nasional.kontan.co.id/news/nadiem-makarim-kami-ingin-cepat-dan-seamanmungkin-mengembalikan-belajar-di-sekolah

CNN Indonesia. (2020, Agustus 20). Menko PMK: PJJ Lebih Banyak Minus. Retrieved from CNN Indonesia: https://www.cnnindonesia.com/nasional/20200820130330-20537636/menko-pmk-pjj-lebih-banyak-minus

Febryan, \& Rizkyan Adiyudha, R. L. (2020, Juli 20). Catatan Kesemrawutan PJJ, dari Guru hingga Fasilitas. Retrieved from Online: https://republika.co.id/berita/qdrrgu328/catatan-kesemrawutan-pjj-dari-guruhingga-fasilitas

Harususilo, Y. E. (2020, Maret 20). Nadiem Ajak Guru dan Dosen Juga "Work from Home", Mengajar dari Rumah. Retrieved from Kompas.com: https://www.kompas.com/edu/read/2020/03/20/145705271/nadiem-ajak-guru-dandosen-juga-work-from-home-mengajar-dari-rumah

Ihsan, D. (2020, September 11). Mendikbud Susun Kebijakan Pembelajaran Terbaik di Masa Pandemi. Retrieved from Kompas.com: https://www.kompas.com/edu/read/2020/09/11/182639071/mendikbud-susunkebijakan-pembelajaran-terbaik-di-masa-pandemi 
JPNN.com. (2020, Agustus 16). Catatan Ombudsman tentang Pelaksanaan PJJ di Masa Pandemi Covid-19. Retrieved from JPNN.com: https://www.jpnn.com/news/catatanombudsman-tentang-pelaksanaan-pjj-di-masa-pandemi-covid-19

Kamil, I. (2020, September 3). Kilas Balik Pembelajaran Jarak Jauh akibat Pandemi Covid-19. $\begin{array}{lll}\text { Retrieved from } \quad \text { Kompas.com: } & \text { f }\end{array}$ https://nasional.kompas.com/read/2020/09/03/10063201/kilas-balik-pembelajaranjarak-jauh-akibat-pandemi-covid-19?page=all

Liputan6.com. (2020, Agustus 29). KPAI Minta Pemerintah Memetakan Masalah Terkait PJJ di Masa Pandemi Covid-19. Retrieved from Liputan6.com: https://www.liputan6.com/news/read/4342900/kpai-minta-pemerintah-memetakanmasalah-terkait-pjj-di-masa-pandemi-covid-19

Media Indonesia. (2020, Juli 15). PJJ di Daerah 3T Temui Banyak Kendala. Retrieved from Media Indonesia: https://mediaindonesia.com/read/detail/328339-pjj-di-daerah-3t-temuibanyak-kendala

Ramadhan, M. S. (2020, April 24). Survei Kemendikbud: 54\% Sekolah Menerapkan Belajar dari Rumah. Retrieved from Medcom.id: https://www.medcom.id/pendidikan/newspendidikan/8koB4X5b-survei-kemendikbud-54-sekolah-menerapkan-belajar-darirumah\#: :text=Survei\%20Kemendikbud\%3A\%2054\%25\%20Sekolah\%20Menerapkan \%20Belajar\%20dari\%20Rumah,Muhammad\%20Syahrul\%20Ramadhan\&text=Jakarta $\% 3 \mathrm{~A} \% 20$

Shofa, J. N. (2020, Mei 5). Mengajar dari Rumah, Nadiem Ajak Guru Keluar dari Zona Nyaman. Retrieved from BeritaSatu.com: https://www.beritasatu.com/jayanty-nadashofa/nasional/628869/mengajar-dari-rumah-nadiem-ajak-guru-keluar-dari-zonanyaman

Sulaiman, R. (2020, Juni 24). Pandemi Covid-19, Jumlah Guru yang Dibutuhkan Naik 1.000 Persen. Retrieved from Suara.com: https://www.suara.com/lifestyle/2020/06/24/205132/pandemi-covid-19-jumlah-guruyang-dibutuhkan-naik-1000-persen

Widyanuratikah, I. (2020, Juni 17). Pemerintah Harus Pikirkan Kesiapan Guru dalam PJJ. Retrieved from Republika

Online: 
https://republika.co.id/berita/qc2383428/pemerintah-harus-pikirkan-kesiapan-gurudalam-pjj

Zubaidah, N. (2020, Oktober 28). Setahun Kemendikbud, Pelatihan Guru Terus Ditingkatkan. Retrieved from

SINDOnews: https://edukasi.sindonews.com/read/211502/212/setahun-kemendikbud-pelatihanguru-terus-ditingkatkan-1603854608

\section{Website}

Muhammad, H. (2020). Menyiapkan Pembelajaran di Masa Pandemi: Tantangan dan Peluang. Jakarta: Kementerian Pendidikan dan Kebudayaan.

P3GTK. (2020, Juli 7). KEPEMIMPINAN PEMBELAJARAN: MERDEKA BELAJAR, MERDEKA MENGAJAR. Retrieved from Kementerian Pendidikan dan Kebudayaan: https://p3gtk.kemdikbud.go.id/konten/kepemimpinan-pembelajaran-merdekabelajar-merdeka-mengajar-37kwq8fb

Pengelola Web Kemdikbud. (2020, Juli 7). Kemendikbud Permanenkan Ketersediaan Platform Teknologi Belajar bukan Metode Pembelajaran Jarak Jauh. Retrieved from Kementerian Pendidikan dan Kebudayaan: https://www.kemdikbud.go.id/main/blog/2020/07/kemendikbud-permanenkanketersediaan-platform-teknologi-belajar-bukan-metode-pembelajaran-jarak-jauh Pengelola Web Kemdikbud. (2020, Agustus 7). Kemendikbud Terbitkan Kurikulum Darurat pada Satuan Pendidikan dalam Kondisi Khusus. Retrieved from Kementerian Pendidikan dan Kebudayaan: https://www.kemdikbud.go.id/main/blog/2020/08/kemendikbudterbitkan-kurikulum-darurat-pada-satuan-pendidikan-dalam-kondisi-khusus

Pengelola Web Kemdikbud. (2020, Mei 29). Kemendikbud Terbitkan Pedoman Penyelenggaraan Belajar dari Rumah. Retrieved from Kementerian Pendidikan dan Kebudayaan: https://www.kemdikbud.go.id/main/blog/2020/05/kemendikbud-terbitkan-

pedoman-penyelenggaraan-belajar-dari-rumah

\section{Website Document}

Badan Pusat Statistik. (2020). Statistik Indonesia 2020. Badan Pusat Statistik.

Jayani, D. H. (2019, Desember 11). Jumlah Guru yang Tersertifikasi Belum Sampai 50\%. Retrieved from Katadata.co.id: https://databoks.katadata.co.id/datapublish/2019/12/12/gurusertifikasi-belum-sampai-50 
Kemdikbud. (2020, Oktober 7). Statistik Usia Guru. Retrieved from Kementerian Pendidikan dan Kebudayaan: http://dashboardgtk.data.kemdikbud.go.id/ptk_usia.php?id=2

PDSPK. (n.d.). Data Pokok Pendidikan-Kebudayaan. Retrieved from Website Pengelolaan Data Pendidikan dan Kebudayaan: http://dapodik.data.kemdikbud.go.id/

\section{Miscellaneous}

Baert, S., Lippens, L., Eline, M., Sterkens, P., \& Weytjens, J. (2020). The COVID-19 Crisis and Telework: A Research Survey on Experiences, Expectations and Hopes. IZA - Institute of Labor Economics.

Nurhayati, T. (2016). Problematika Guru dalam Menguasai TIK (Teknologi Informasi dan Komunikasi) Pada Pembelajaran Pendidikan Agama Islam dan Solusinya di MI Al-Asy'ari Kuniran Batangan Kabupaten Pati Tahun Ajaran 2015/2016. Semarang: Universitas Islam Negeri Walisongo.

Pratiwi, N. W. (2016). Kompetensi Guru Berdasarkan Jenis Kelamin, Usia, Pengalaman Mengajar, dan Tingkat Pendidikan. Yogyakarta: Universitas Sanata Dharma. 